\title{
Gerakan damai ala kelompok-kelompok islamis di dunia Islam
}

\author{
Adang Kuswaya \\ STAIN Salatiga, Jl. Tentara Pelajar No.02 Salatiga \\ Email:dangkuswaya@gmail.com
}

Judul buku : Umat Bergerak Mobilisasi Damai Kaum Islamis di Indonesia, Malaysia, dan Turki

Penulis : Julie Chervov Hwang

Penerbit : Freedom Institute

Tahun terbit : 2011

Halaman : $x x i v+342$

\section{Pendahuluan}

Judul buku yang diberikan penerbit Umat Bergerak Mobilisasi Damai Kaum Islamis di Indonesia, Malaysia, dan Turki. Sedangkan judul buku yang diberikan penulis Peaceful Islamist Mobilization in The Muslim World. Sepintas penulis berfikir bahwa judul penulisan penerjemahan ke dalam bahasa Indonesia tersebut dilakukan supaya lebih memikat perhatian dari pembaca. Untuk itu,, penulis memilih judul review untuk buku ini dengan "Gerakan damai ala kelompok-kelompok islamis di dunia Islam".

Bahtiar Effendy -sebagai pemberi pengantar buku ini- mengatakan bahwa kehadiran buku ini sangat penting setidaknya karena dua hal. Pertama, karya Julie Chernov Hwang selanjutnya Hwang- ini merupakan buku serius yang ada, yang menjelaskan tentang pergerakan Islam kontemporer di tiga negara - Turki, Malaysia, dan Indonesia. Pendekatan yang diberikan 
ljtihad, Jurnal Wacana Hukum Islam dan Kemanusiaan, Volume 13, No. 2, Desember 2013: 291-302

oleh Hwang membeberkan persamaan dan perbedaan gerakan-gerakan Islam yang ada. Kedua, tulisan Hwang menempatkan bahwa negara merupakan faktor penting yang turut mempengaruhi format dan isi gerakan Islam kontemporer yang cukup bervariasi.

Untuk kasus di Asia buku ini, mengaji empat kasus Muslim Asia: Indonesia di bawah Orde Baru (1966-1998), Indonesia masa reformasi (1998-sekarang), Malaysia, dan Turki. Negara-negara tersebut dipilih oleh Hwang untuk mengalihkan perhatian yang terlalu besar terhadap dunia Arab. Mayoritas buku-buku yang ditulis mengenai Islam pada hari ini menyorot kasus-kasus Arab; tetapi, negeri-negeri paling demokratik dan makmur di dunia Muslim terdapat di Asia Islam, di mana lebih dari 50 persen Muslim tinggal.

Hwang yang melakukan risetnya di Indonesia, Malaysia, Turki, dan Singapura pada tahun 2005, 2006, dan 2008, mencakup lebih dari 100 wawancara dengan pelaku-pelaku kunci. Selain waktunya untuk melakukan riset di perpustakaan-perpustakaan, dia tidak jarang menghadiri di antaranya demonstrasi-demonstrasi, kongres-kongres partai, diskusi-diskusi panel, konferensi-konferensi, lokakarya-lokakarya, pidato-pidato, dan rapat-rapat LSM-LSM tentang topik-topik yang berkenaan dengan buku ini.

Penulis sepakat dengan Bahtiar Efendi yang mengatakan bahwa apa yang terjadi di Turki, Malaysia, dan Indonesia adalah ekspresi keprihatinan orang Islam mengenai posisi dan peran Islam. Dalam konteks ini, akomodasi menjadi kunci utamanya. Islam dan negara dituntut untuk menegosiasikan kepentingan mereka dalam kerangka bangunan negara yang telah ada. Karya Hwang ini berupaya memberikan gambaran lengkap dengan menginvestigasi variasi dalam strategi-strategi mobilisasi kelompok Islamis dan menyorot cara-cara positif dan negatif yang bisa dipakai negara untuk mempengaruhi strategi-strategi itu.

\section{Julie Chernov Hwang dan pemetaan penelitian}

Saat ini Hwang merupakan asisten profesor pada Departemen Ilmu Politik dan Hubungan Internasional di Goucher College, Maryland, Amerika Serikat. Bidang utama risetnya adalah tentang hubungan antara negara dan kelompok Islamis, partai-partai politik Islamis, sebabsebab radikalisasi dan keterasingan, serta tentang berbagai konflik etnis yang terjadi di dalam masyarakat majemuk. 
Buku terjemahan dalam bahasa Indonesia ini merupakan hasil riset disertasi doktoralnya di Universitas Colorado, Boulder, yang kemudian diterbitkan oleh Palgrave Press pada 2009. Beberapa bab buku yang menurut pengakuannya pernah ditulisnya termasuk "Education and Social Cohesiotl in Malaysia and Indonesia," terbit dalam Religious Diversity and Civil Society: A Comparative Analysis (Ed. Bryan Turner. Oxford: Bardwell Press, 2008). Artikel jurnalnya termasuk "When Parties Swing: Islamist Parties and Institutional Moderation in Malaysia and Indonesia," dalam Southeast Asia Research pada Desember 2010. Artikel-artikel lain terbit pula di Nationalism and Ethnic Politics dan Katha: The Journal of the Center for Civlizational Dialog. Terakhir, Hwang sedang menjadi salah satu penyunting sebuah buku tentang perilaku partai politik Islamis, yang menggunakan berbagai kasus dari Asia Tenggara, Asia Selatan, Timur Tengah, dan Afrika Utara.

Menurut Hwang (2011:24) Malaysia 58 persen Muslim, dan sistem politiknya adalah campuran komponen-komponen, baik yang demokratik maupun otoriter, sementara Turki 99 persen Muslim dan adalah rejim demokratik dengan militer yang berpengaruh. Di Turki dan Malaysia, Islamis-Islamis sudah lama bisa membentuk partai-partai politik dan bersaing dalam pemilihan-pemilihan umum sementara Indonesia, dengan 88 persen mayoritas Muslim, mengisahkan dua cerita yang sangat berbeda.

Di Indonesia, riset dilakukan di tiga kota yang terkenal akan aktivisme Islam: Jakarta, Yogyakarta, dan Solo. Menurut Hwang (2011: 27) Yogyakarta mengalami mobilisasi yang sebagian besar bersifat damai, sedangkan Solo dikenal sebagai basis banyak pergerakan Islamis radikal. Hwang mengunjungi pesantren-pesantren yang dikelola oleh Nandlatul Ulama yang berada di Bogor dan Yogyakarta. Terakhir, Hwang mewawancarai pemimpinpemimpin beberapa LS M internasional untuk mengetahui asesmen mereka akan kekuatan dan kelemahan institusi-institusi politik Indonesia, tantangan-tantangan yang dihadapi Indonesia dalam hal hukum dan ketertiban.

Di Malaysia, menurut Hwang (2011: 28) waktunya terbagi antara Kuala Lumpur dan negara bagian Kelantan. Hwang mewawancarai di antaranya pemimpin-pemimpin Angkatan Belia Islam Malaysia (ABIM), Sisters in Islam, Perkim, International Movement for a Just World (JUST), dan Jamaah Isiah Malaysia (JIM); anggota-anggota parlemen dari United Malays National Organization, Malaysian Chinese Association, dan Parti Islam Se-Malaysia 
ljthad, Jurnal Wacana Hukum Islam dan Kemanusiaan, Volume 13, No. 2, Desember 2013: 291-302

(PAS). Hwang mendalami mengapa mobilisasi kekerasan oleh kelompok-kelompok Islamis sangat jarang di Malaysia, dan bagaimana pemerintah Malaysia menyediakan layanan-layanan sosial.

Di Turki, Hwang (2011: 29) melakukan riset di dua kota: Istanbul dan Ankara. Dia mewawancarai di antaranya para akademisi di Universitas Teknik Timur Tengah, Ankara, dan Universitas Fatih, Istanbul. Para pakar ini menurut Hwang memberikan pengetahuan mendalam mengenai hubungan antara negara dan kelompok-kelompok Islamis di Turki. Hwang juga beruntung mewawancarai aktivis-aktivis dari Fetullah Gulen dan kepala Diyanet Isleri Baskanligi (Direktorat Urusan Agama).

\section{Gerakan kelompok-kelompok islamis di Turki}

Di Turki, negara memperbolehkan partisipasi lewat jalur-jalur institusional yang sah. Sebagian besar pergerakan Islamis Turki memakai jalur-jalur ini untuk bekerja mencapai tujuan-tujuan mereka. Mereka membentuk partai-partai politik, bersaing dalam pemilihan-pemilihan umum. Sebagai kelompok-kelompok masyarakat sipil, tarekat-tarekat, yayasan-yayasan, dan asosiasi-asosiasi Islam, mereka boleh menjalin aliansi-aliansi informal dengan partai-partai politik untuk mencapai tujuan-tujuan bersama (Hwang: 2011:65).

Kapasitas negara Turki untuk memastikan hukum dan ketertiban di dalam perbatasannya sangat beragam, dari sangat inefektif sampai sangat efektif. Turki mengalami peningkatan kekerasan yang dilakukan oleh milisi komunis dan ultranasionalis pada 1960-an dan 1970an. Ini diakibatkan ketidakmampuan negara Turki untuk secara konsisten memelihara hukum dan ketertiban di dalam wilayahnya, Pada 1990-an, ketidakmampuan negara Turki untuk mempertahankan hukum dan ketertiban di dalam perbatasannya memberikan kesempatan kepada kelompok-kelompok Islamis radikal seperti Hizballah dan IBDA-C untuk mendapatkan kemajuan masuk ke dalam masyarakat di Tenggara, untuk mendapatkan rekrut baru, dan untuk melakukan kontak dengan kekuatan-kekuatan eksternal seperti Iran, yang melatih dan mendanai mereka.

Negara Turki sangat efektif dalam menyediakan layanan pendidikan dan kesehatan kepada rakyat. Negara mendominasi lingkup pendidikan, memonitor kurikulum, memastikan kepatuhan terhadap kurikulum, mengambil tindakan terhadap perkembangan sekolah-sekolah 
imam--hatip yang tak terkendali, dan menyediakan pendidikan agama di sekolah-sekolah urnum. Semua ini menghambat kemampuan kelompok-kelompok radikal untuk mendapatkan jalan masuk di bidang ini (Hwang: 2011:66).

\section{Gerakan kelompok-kelompok islamis di Indonesia masa orde baru dan reformasi}

Kekurangan-kekurangan rejim Soeharto dalam penyediaan hukum dan ketertiban tidak menimbulkan intervensi oleh kekuatan-kekuatan eksternal. Dalam kasus Indonesia, Abu Bakar Ba'asyir dan Abdullah Sungkar, kepala-kepala pesantren Ngruki dan pendiri-pendiri Jemaah Islamiyah (JI), lari meninggalkan Indonesia menuju Malaysia pada 1985, setelah dilepaskan dari penjara karena menjadi anggota Komando Jihad. Di Malaysia, mereka memelopori upaya-upaya pengiriman orang Indonesia ke Afghanistan. Ketika Soeharto jatuh, JI menetapkan Indonesia sebagai lahan perekrutan utama.

Kekuatan eksternal besar lain yang berdampak pada rejim Orde Baru adalah Krisis Finansial Asia 1997. Soeharto menolak memberlakukan unsur-unsur program IMF yang akan berdampak buruk pada keluarga dan kroni-kroninya; harga-harga bahan-bahan pangan pokok naik sampai 80 persen dan pengangguran meningkat."'

Mahasiswa-mahasiswa mulai berdemonstrasi di kampus-kampus perguruan tinggi mereka, menyerukan reformasi. Kerusuhan pecah di kota-kota besar dan menengah. Kemudian, pada 12 Mei 1998, lima mahasiswa meninggal di Universitas Trisakti sehingga anggota-anggota kabinet dan komunitas Muslim mulai secara terbuka menyerukan Soeharto agar turun. Karena rejim Orde Baru tidak lagi mampu menjaga periuk nasi, atau memelihara hukum dan ketertiban, Soeharto menyerah pada 20 Mei 1998. Setelah itu, menjamurlah mobilisasi, baik yang secara damai maupun yang berkekerasan (2011: 106-109).

Kekuatan-kekuatan eksternal telah memperparah kekerasan di Indonesia secara lebih luas daripada di Malaysia atau Turki. Jaringan teroris Jemaah Islamiyah (JI) dan veteranveteran Afghan. Fenomena veteran Afghan sangat penting untuk memahami peran yang dimainkan kekuatan-kekuatan eksternal. Banyak di antara mujahidin yang pergi bertempur di Afghanistan, mendirikan organisasi-organisasi Islamis radikal di negeri asal mereka. Indonesia tidak terkecuali (2011: 156). 
ljtihad, Jurnal Wacana Hukum Islam dan Kemanusiaan, Volume 13, No. 2, Desember 2013: 291-302

Jemaah Islamiyah (JI) didirikan oleh dua ulama Indonesia, Abdullah Sungkar dan Abu Bakar Ba'asyir, di Malaysia, dan telah menyebar di seluruh Asia Tenggara dan Australia. Jaringan teroris JI adalah pelaku tunggal yang bertanggungjawab atas makin parahnya kekerasan Islamis di Indonesia. JI melakukan pengeboman beberapa tempat di Bali dan di Jakarta. Menurut Nasir Abas, (2011: 157-158) JI berubah setelah Osama bin Laden pada 1998 menyatakan bahwa kegiatan teror terhadap target sipil boleh dilakukan. Pada 2000, Hambali dan pengikutnya melakukan serangkaian pengeboman gereja di Medan. Namun, bombom itu memicu penduduk kota bersatu dan sepakat menolak kekerasan; dan sebaliknya mereka tidak berhasil mengipasi ketegangan Kristen-Muslim. Jadi, dalam kasus ini, masyarakat sipil Islam memperkuat upaya pemerintah.

Pemerintah Indonesia patut dipuji untuk kemajuan-kemajuan besar dalam memelihara hukum dan ketertiban pada skala besar. Mungkin yang paling menarik, ketika polisi menangkapi pemimpin-pemimpin dan anggota-anggota milisi-milisi, tidak ada serangan balik. Mereka telah mengalah terhadap hukum Indonesia. Menurut Dr. Bahtiar Effendy, ini mengindikasikan, "Kalau negara bertindak sebagai negara, akan ada rasa hormat. Anda lantas tahu apa yang tidak bisa anda lakukan. Indonesia bukan negara Islam ".

Keberhasilan Indonesia dalam menyediakan pendidikan dan kesejahteraan tidak merata. Hal ini menyebabkan negara dipandang sebagai tidak efektif, tetapi kelompok-kelompok Islamis radikal jarang bisa mengambil keuntungan dari kelalaian negara ini untuk meningkatkan dukungan rakyat terhadap mereka, karena upaya-upaya tambahan yang dominan dari NU dan Muhammadiyah. Tapi, di Maluku dan Poso, Laskar Jihad berhasil mengambil-alih fungsi negara dengan menawarkan keamanan, pendidikan, dan layanan pengobatan. Pada tahuntahun belakangan, di bawah pemerintahan Presiden Susilo Bambang Yudhoyono, penyediaan negara akan pendidikan, layanan kesehatan, dan bantuan pada orang miskin telah mulai membaik.

Selama sepuluh tahun ini, Indonesia telah bertransisi dari sistem otoriter efektif menjadi sistem partisipatoris inefektif. Sementara negara terus meningkatkan ketegasannya dalam hukum dan ketertiban serta kompetensinya dalam penyediaan layanan sosial, Hwang memprediksi bahwa Indonesia mungkin akan segera bertransisi lagi menjadi sistem partisipatoris efektif. 


\section{Gerakan kelompok-kelompok islamis di Malaysia}

Dari semua studi kasus dalam buku ini, mobilisasi kekerasan Islamis paling jarang terjadi di Malaysia. Ini disebabkan penerapan strategi terpadu oleh negara. Walaupun sistem politik Malaysia tidak sedemokratik dan seterbuka Indonesia pasca-Orde Baru atau pun Turki, ia menyediakan jalur-jalur untuk partisipasi politik, dan kelompok-kelompok Islamis telah memenangi banyak kemenangan-kemenangan kecil dengan memanfaatkan jalur-jalur ini. Mereka bergabung dengan UMNO dan berusaha menggapai cita-cita mereka melalui parlemen dan birokrasi.

Aparatur keamanan Malaysia memastikan bahwa daerah-daerah tak berhukum tidak muncul. Dengan demikian, tidak ada kelompok Islamis radikal yang mengambil-alih tempat negara. Ia juga pada umumnya lebih suka menjalankan hukum dan ketertiban untuk memastikan bahwa kelompok-kelompok Islamis radikal tidak bertindak sewenangwenang terhadap orang lain. Kalau kelompok-kelompok itu tidak mau bekerja mencapai tujuantujuan mereka lewat jalur-jalur institusional yang sah negara akan mengambil langkah-langkah melarang organisasi-organisasi, memantau mereka, atau, bila perlu, menangkap mereka dan memenjarakan mereka.

Negara Malaysia mendominasi penyediaan pendidikan dan kesejahteraan dan meraup legitimasi substansial dari keberhasilan Dasar Ekonomi Baru (DEB) dan Dasar Pendidikan Kebangsaan, yang mengurangi kemiskinan dan memungkinkan banyak orang Melayu menjadi kelas menengah. Kelompok-kelompok Islamis memainkan peran penting dalam membantu upaya negara. Dalam pendidikan, pemerintah-pemerintah federal dan negara bagian menyediakan pendidikan umum dan pendidikan agama. Mayoritas besar kelompokkelompok Islamis juga taat pada persyaratan-persyaratan kurikuler yang diwajibkan negara, agar murid-murid mereka mendapatkan pendidikan tersier di universitas-universitas Malaysia.

Terakhir, lewat penyediaan efektif hukum dan ketertiban, Malaysia telah berhasil membatasi pengaruh kekuatan kekuatan eksternal. Lewat kooperasi dengan badan-badan intelijen Singapura dan Amerika, badan-badan keamanan Malaysia menangkapi anggotaanggota Jemaah lslamiyah sebelum mereka bisa melakukan operasi besar apa pun di Malaysia, dan melumpuhkan kapasitas operasi organisasi itu di negeri itu. 
ljtihad, Jurnal Wacana Hukum Islam dan Kemanusiaan, Volume 13, No. 2, Desember 2013: 291-302

Bisakah orang berbicara tentang model Malaysia yang harus diterapkan secara luas? Mungkin tidak. Malaysia adalah negeri kecil, terbagi-bagi secara etnis, dengan tradisi panjang politik koalisi tak terputus, dan memori historic yang unik. Tapi mungkin kasus Malaysia bisa memberikan pelajaran umum-tentang manfaat-manfaat model partisipatoris efektif, pentingnya jalur-jalur untuk partisipasi politik, dan perlunya kapasitas negara yang efektifuntuk negara-negara lain yang sedang berusaha mendorong mobilisasi damai dan melemahkan kekerasan yang dilakukan atas nama Islam.

Analisis perbandingan antarnegara di dunia Islam

Dari analisis perbandingan yang singkat mengindikasikan bahwa kerangka kerja teoretis yang diajukan dalam buku ini punya daya aplikasi yang lebih luas di dunia Muslim yang lebih lebar, dengan kualifikasi-kualifikasi tertentu. Misalnya, Kuwait menyediakan beberapa jalur untuk inklusi politik, yang cukup institusional, sambil mempertahankan kapasitas efektif baik dalam hal hukum dan ketertiban maupun pendidikan dan layanan sosial.

Sistem tersebut di atas menurut Hwang (2011:233) walaupun tidak seterbuka Bangladesh atau Yaman, menyediakan akses politik untuk berbagai arus Islam, dan Syiah sampai Salafi sampai Al-Ikhwan Al-Muslimun. Walaupun dekat dengan Irak, perang di sana tidak sampai memberikan dampak sampingan separah yang terjadi di Turki, dan intervensi oleh al Qaeda bersifat minimal.

Dalam kelompok kasus-kasus kedua, Yaman dan Bangladesh memiliki jalur-jalur institusional untuk partisipasi politik lebih besar daripada Kuwait, tapi negara tidak bisa menyediakan pendidikan dan layanan kesejahteraan atau memastikan jangkauan otoritas yang efektif. Walaupun terdapat tingkat tinggi mobilisasi Islamis lewat jalur-jalur damai, kekerasan juga menjadi taktik yang sering dipakai. Di negara-negara ini ketidakmampuan menyediakan pendidikan dan kesejahteraan sosial memungkinkan kelompok-kelompok Islamis bergerak memenuhi kekosongan, dalam prosesnya mendapatkan pengikut. Baik di Bangladesh maupun Yaman, ketidakmampuan negara menyediakan pendidikan komprehensif telah memungkinkan kelompok-kelompok radikal, dibantu pendanaan dan kelompok-kelompok neo- Salafi dan Wahabi, untuk membuka ratusan madrasah radikal.

Intervensi oleh kekuatan-kekuatan eksternal, khususnya, tinggi di negeri-negeri ini-pendanapendana Salafi dan Wahabi menyubsidi sekolahsekolah Islam ortodoks dan organisasi- 
organisasi kesejahteraan sosial; veteran-veteran Afghan mendirikan organisasi- organisasi militan di daerah-daerah tak berhukum; dan al Qaeda serta organisasi-organisasi teroris lain melakukan kegiatan-kegiatan di daerah- daerah itu.

Terakhir, seperti halnya Indonesia Orde Baru, Bahrain menunjukkan kekurangankekurangan sistem otoritarianisme efektif. Dengan menolak mendirikan bahkan sekadar jalur-jalur untuk partisipasi politik ala Kuwait, tidak banyak jalan bagi mayoritas Syiah untuk menyatakan ketidakpuasan mereka atau membuat suara mereka terdengar. Ketika petisi tidak menghasilkan reformasi politik dan sosio-ekonomi yang lebih besar, orang-orang Syiah yang tidak puas, dan orang-orang Sunni, liberal, dan orang-orang kin yang berpikiran serupa, turun ke jalan. Badan-badan keamanan tidak membeda-bedakan pergerakan yang mendorong kesetaraan sosio-ekonomi lebih besar dengan mereka yang menggunakan kekerasan.

Bahrain pada pertengahan 1990-an terguncang oleh serangan-serangan pembakaran dan pengeboman. Walaupun badan-badan keamanan sampai saat itu dipandang efektif, mereka tidak sanggup menghentikan kekerasan. Penurunan dalam layananlayanan sosial ikut menambah ketegangan. Walaupun pemerintah menyediakan pendidikan dan layanan kesehatan, tidak ada jaring pengaman sosial untuk penganggur Syiah.

\section{Saran untuk negara terhadap kelompok-kelompok islamis radikal}

Buku ini menunjukkan bahwa penyediaan hukum dan ketertiban tidak menuntut pemakaian represi dengan kekerasan yang sering dilakukan negara. Kenyataannya, represi dengan senjata semata-mata malah bisa menambah alienasi dan pembalasan strategik mobilisasi kekerasan. Kasus-kasus bertolak belakang Malaysia dan Indonesia Orde Baru menunjukkan dua negara dengan aparatus represif yang berbeda. Di Malaysia, negara mengandalkan kekuatan hukum untuk menekan kelompok-kelompok Islamis radikal alih-alih menggunakan kekuatan senjata.

Indonesia Orde Baru memakai represi kekerasan semata-mata lebih sering daripada Malaysia, tetapi mobilisasi kekerasan justru lebih sering terjadi. Ada kesejajaran kuat antara insiden Al Ma'unah 2000 di Malaysia dan insiden Lampung 1989 di Indonesia pada permukaannya. Menarik menganalisis piihan reaksi negara Indonesia di Lampung. Seperti Al Ma'unah, ada bukti bahwa komune Lampung menimbun senjata. Alih-alih mengambil 
ljtihad, Jurnal Wacana Hukum Islam dan Kemanusiaan, Volume 13, No. 2, Desember 2013: 291-302

langkah-langkah meminimalkan korban sambil masih menjalankan hukum, militer menyerbu tempat itu, menewaskan lebih dan 100 Islamis, termasuk wanita dan anak-anak.

Otoritas Malaysia mengambil langkah meminimalkan korban dan memakai kekuatan hukum terhadap militan-militan Al Ma'unah yang dalam jangka panjang berhasil lebih baik daripada strategi Orde Baru dengan kekuatan senjata semata-mata. Walaupun jumlah korban besar di Lampung, respons negara tidak menghilangkan mobilisasi kekerasan Islamis. Bahkan, ia meradikalkan anggota-anggota komune sisanya dan Islamis-Islamis garis keras lain.

Menurut pernyataan Dr. Othman bahwa kapasitas negara untuk memakai kekuatan senjata bisa jadi sudah cukup untuk melemahkan tindak-tindak kekerasan. Represi dengan kekuatan hukum lebih mungkin diterima oleh organisasi-organisasi Islamis, dan ia akan berdampak pada bagaimana kelompok-kelompok itu bermobilisasi. Namun, represi kekuatan senjata yang mengakibatkan ratusan orang tewas justru hanya memperparah alienasi Islamis dan membuat mereka semakin teradikalisasi.

\section{Penutup}

Arti penting negara dalam kaitannya dengan perkembangan gerakan Islam kontemporer menjadi sangat nyata. Negara dengan sistem pemerintahan yang sekularistik semisal Turki telah memunculkan pola dan bentuk gerakan Islam kontemporer yang berbeda dengan yang berkembang di negara-negara lain seperti Malaysia atau Indonesia. Turki sebagai negara yang pernah mengalami proses transformasi politik dari partisipatori tidak-efektif menjadi partisipatori efektif, dengan kapasitas yang baik, mendatangkan gerakan politik keislaman seperti yang berkembang dalam sejarah Islam kontemporer Turki.

Tidak sama dengan gerakan serupa yang berkembang di Malaysia dan Indonesia, politik di Turki harus mempertimbangkan dimensi sekularisme di dalam menyuarakan gagasan dan memperjuangkan kepentingan mereka. Warna dan substansi Islam harus dikemas sedemikian rupa sehingga tidak melanggar rambu-rambu sekularisme yang seakan disakralkan khususnya oleh tentara. Sekali rambu sekularisme ditabrak, hal itu bisa berujung dengan dibubarkannya partai, sebagaimana yang dialami Partai Refah.

Posisi Indonesia bisa dikatakan antara Turki dan Malaysia. Lebih kental warna Islamnya dibanding Turki, akan tetapi lebih liberal dibanding Malaysia. Elite politik di Indonesia dalam 
sejarahnya tidak memutuskan Islam sebagai agama negara. Meskipun, ketika dasar negara diberdebatkan, 90\% penduduknya beragama Islam. Paling banter mereka menempatkan prinsip Ketuhanan Yang Maha Esa sebagai sila pertama dalam dasar negara Pancasila. Akibatnya, slogan yang dikenal adalah "Indonesia bukan negara agama, tetapi juga bukan negara sekuler."

Kasus Indonesia mengilustrasikan banyak kemajuan yang dicapai negeri-negeri Muslim ke arah pembangunan demokratik dan rintangan-rintangan yang masih dihadapi negerinegeri dalam menghambat mobilisasi kekerasan. di seluruh dunia Muslim, di Yordania, Bahrain, Maroko, Turki, dan Malaysia, sistem-sistem politik sedang mengalami liberalisasi. Ada negeri, seperti Malaysia dan Maroko, yang punya sejarah panjang aktivitas damai dan, di masa depan yang bisa diperkirakan, kelompok-kelompok Islamis akan terus bermobilisasi dengan memakai jalur-jalur konstruktif yang tersedia bagi mereka. Namun, seperti yang diprediksi Hwang (2011: 26) di negeri-negeri lain, seperti Pakistan, Yaman, dan Bangladesh, masa depan tetap suram; negara-negara ini mengalami tingkat mobilisasi kekerasan yang makin atau tetap tinggi, yang telah mendestabilisasikan seluruh wilayah atau provinsi.

Kasus-kasus singkat ini membuktikan bahwa negara-negara yang memiliki baik kapasitas efektif maupun jalur-jalur institusional lebih mampu mendorong kelompok-kelompok Islamis untuk menerima strategi-strategi damai dan meninggalkan kekerasan, dibandingkan dengan negara-negara yang hanya punya salah satu dan kedua unsur itu. Apabila negara undur dan penyedian barang dan layanan publik, pergerakan-pergerakan Islamis radikal dapat memanfaatkan kesempatan-kesempatan itu untuk mendapatkan legitimasi dengan merugikan negara.

Saran bagi negara untuk memakai kekuatan senjata bisa jadi sudah cukup untuk melemahkan tindak-tindak kekerasan. Represi dengan kekuatan hukum lebih mungkin diterima oleh organisasi-organisasi Islamis, dan ia akan berdampak pada bagaimana kelompokkelompok itu bermobilisasi. Namun, represi kekuatan senjata yang mengakibatkan ratusan orang tewas justru hanya memperparah alienasi Islamis dan membuat mereka semakin teradikalisasi. 
ljtihad, Jurnal Wacana Hukum Islam dan Kemanusiaan, Volume 13, No. 2, Desember 2013: 291-302

\section{Daftar Pustaka}

Aras, Bulent dan Omer, "Fethullah Gulen and his Liberal 'Turkish Islam" Movement, Middle East review of International Affairs, No.4. Desember 2000.

Effendy, Bahtiar, "Pengantar buku Umat Bergerak Mobilisasi Damai Kaum Islamis di Indonesia, Malaysia, dan Turki.” Jakarta: Freedom Institute, 2011.

Effendy, Bahtiar. Islam and the State: Transformation of Islamic Political Ideas and Practices in Indonesia, Disertation, Ohio State University, 1994.

Effendy, Bahtiar. Islam dan Negara:Transformasi Pemikiran dan Praktik Politik Islam di Indonesia, Jakarta: Paramadina, 1998.

Effendy, Bahtiar. Teologi Baru Politik Islam. Yogyakarta: Galang, 2011.

Effendy, Bahtiar, Islam and State in Indonesia. Singapura: Institute of Southeast Asian Studies/ 2003.

Hwang, Julie Chernov. Umat Bergerak Mobilisasi Damai Kaum Islamis di Indonesia, Malaysia, dan Turki, Jakarta: Freedom Institute, 2011.

Hwang, Julie Chernov, “Terrorism in Perspective: An Assessment of 'Jihad Project' Trends in Indonesia". Analysis from the East-West Center No. 104 September 2012: 1-12. 